\title{
LANGUAGE OF EVALUATION ON ATTITUDINAL SYSTEM OF LOMBOK TOURISM PROMOTION
}

\author{
Dewi Retno Indawati ${ }^{1}$, Rosyida Ekawati ${ }^{2}$ \\ ${ }^{1,2}$ English Study Program, Faculty of Social and Cultural Sciences, \\ Universitas Trunojoyo Madura, Indonesia \\ Jl. Raya Telang, Kamal, Bangkalan, JawaTimur-Indonesia \\ ${ }^{1}$ dewiretnoindawati.dri@gmail.com, ${ }^{2}$ rosyida.ekawati@trunojoyo.ac.id
}

\begin{abstract}
The study is aimed at explaining the representation of Lombok tourism from the official YouTube of Indonesia tourism. It focuses on the use of verbal languages. The study is a case study of a promotional video entitled Wonderful Indonesia Lombok. The source of data of this study is available at https://www.youtube.com/watch?v=BbkFE_K_t 0 c. This study used the theory of attitudinal system in appraisal language proposed by Martin and White (2005) to describe and explain the language of evaluation in the video. The result of the study shows that video promotion of Lombok tourism emphasizes more on the use of a positive attitude system to attract the visitors and highlight Lombok destinations such as nature, culture, and the product of local people. Positive evaluation on appreciation and effect on the attractions expressed the worthiness of the resources to be visited and enjoyed with. There is an absence of judgment evaluation that deals with attitudes to people and the way they behave their characters. All of the positive evaluation resources merge to be one of the representations of Lombok Island as one of the tourism destinations in Indonesia that is worth visiting.
\end{abstract}

Keywords: Appraisal; Attitudinal System; Lombok; Promotion; Tourism

\begin{abstract}
ABSTRAK
Penelitian ini bertujuan untuk menjelaskan representasi pariwisata Lombok dari YouTube resmi pariwisata Indonesia yang berfokus pada penggunaan bahasa verbalnya. Penelitian ini merupakan studi kasus video promosi yang berjudul Wonderful Indonesia Lombok. Sumber data penelitian ini tersedia di https://www.youtube.com/watch? $v=B b k F E \_K \_t 0 c$. Penelitian ini menggunakan teori sistem sikap dalam bahasa appraisal yang dikemukakan oleh Martin dan White (2005) untuk mendeskripsikan dan menjelaskan bahasa evaluasi dalam video tersebut. Hasil penelitian menunjukkan bahwa video promosi pariwisata Lombok menekankan pada penggunaan sikap positif dalam sistem penilaian untuk menarik pengunjung dan destinasi unggulan Lombok seperti alam, budaya, dan produk masyarakat setempat. Evaluasi yang positif pada system apresiasi dan effect pada tujuan wisata mengungkapkan adanya kelayakan sumberdaya untuk dikunjungi dan dinikmati bersama. Tidak ada evaluasi judgment yang berkaitan dengan sikap terhadap orang dan cara mereka berperilaku. Sетиa sumber evaluasi yang positif tersebut menyatu menjadi salah satu representasi Pulau Lombok sebagai salah satu destinasi pariwisata di Indonesia yang patut untuk dikunjungi.
\end{abstract}

Kata Kunci: Evaluasi; Sistem Sikap; Lombok; Promosi; Pariwisata

\section{INTRODUCTION}

Language as a means of communication plays a significant role in the promotional video. In fact, people use verbal and non-verbal communication to convey a message in their daily life including the promotion of tourism destinations. 
In addition, numerous studies (Zhang, 2011; Molina \& Esteban, 2006; Kim et al., 2005) have shown that the influential part in decision-making to persuade or attract potential tourists is the role of language in introducing and promoting the tourism destination.

Indonesia has various beautiful natural resources, the diversity of culture, language, religion, flora and fauna, etc. In Indonesia, the major components of Indonesia tourism are nature and culture. Moreover, the Lombok destination is one of the best choices of Indonesia tourism. Lombok Island is located in West Nusa Tenggara Province which is selected for the best halal tourism destination in Indonesia Muslim Travel Index (IMTI) in 2019. Therefore, Lombok can be the best choice to be a tourism destination.

Indonesia has to promote its tourism to attract the tourists. The information of Indonesia tourism must be widespread throughout the world to attract more people. The fundamental source of information on the destination for potential tourists comes from tourism promotional media. According to Locksley (2009), the media has a significant part in business activities including the tourism industry. Recently, many destination countries are establishing or improving online marketing such as official government tourism websites, social media accounts Instagram, Facebook, Twitter, and YouTube, with the expectation that the access of the information about tourist destinations will reach the potential tourists.

Indonesia tourism official YouTube account named Indonesia Travel has several videos of destinations to promote several parts of Indonesia that have incredible sceneries including Lombok tourism. Because the official tourism account has the responsibility to maintain the image of Indonesia, the government not only has to develop the infrastructure to support tourism but also prepare the great strategies in online marketing to make outstanding advertisement promotion videos of Indonesian tourism. It is not only from the moving pictures in the video, the verbal languages used in the video that accompany the pictures also have prominent roles in exposing the tourism destinations. Kind of promotional language usually uses positive evaluation toward the destinations. This study tries to explain the use of verbal language, in particular in evaluating the tourism destination in Lombok Island.

Some studies in this similar field were conducted by other scholars. One of them was the study about Malaysian tourism websites conducted by (Salim, Ibrahim, \& Hassan, 2014). This study attempted to examine how the diversity of culture, destinations and architecture of the country are represented in the website. This study focused on the verbal element of the language and visual elements as the data. It is found that both of the elements indicate a strategy to represent the diversity of Malaysia to attract potential tourists.

Another study about the tourism brochures of Malaysian cultures was conducted by (Hassan, 2014). This study aimed to convey the representation of Malaysian culture through the comparison of verbal element or linguistic and visual 
element or non-linguistic modes. Several Malaysia tourism brochures analyzed with qualitative design in multimodal discourse framework. Specific linguistic cues and visual images reveal these cultural elements.

(Isti'anah, 2000) studied language attitudes on Indonesian tourism websites and found that the domination of valuation on the website revealed that Indonesian nature was promoted in terms of its value. The evaluation is in terms of positive appreciation with the absence of affect and judgment.

In the promotional videos, generally there are several elements such as verbal, visual, and audio which is part of verbal and non-verbal communication language to attract the viewers. Those elements will have a relation to create meaning and determine the quality of tourism promotional video. Verbal element, the use of language, provides a kind of evaluation toward the destination. Therefore, this study attempts to analyze the verbal elements in the official YouTube account of Indonesia tourism especially in Wonderful Indonesia Lombok promotional video to understand the representation of Lombok tourism.

\section{LITERATURE REVIEW}

Theory of appraisal is the interpersonal meaning field of Systemic Functional Linguistics (SFL) development for schematizing and investigating the construction of interpersonal meanings in the texts. It involves the language interactions between the producer and the viewers which express the function of speech. According to (Eggins, 1994), it is a language approach of the way the people use the language with others in their social daily life. (Liu, 2010) stated that an analytical tool to get a better understanding of several issues which relates to the evaluative resources and the negotiation of intersubjective positions, opening a new area of interpersonal meaning is appraisal framework.

Appraisal framework is an approach of exploring, describing, and explaining the evaluation of language used, adopting stances, constructing textual personals, and managing the positioning of interpersonal and relationships (Martin and Rose, 2003). Moreover, language appraisal is categorized into three domains, i.e. attitude, engagement, and graduation. 
Graph 1. An Overview of Appraisal Resources (Martin \& White, 2005)

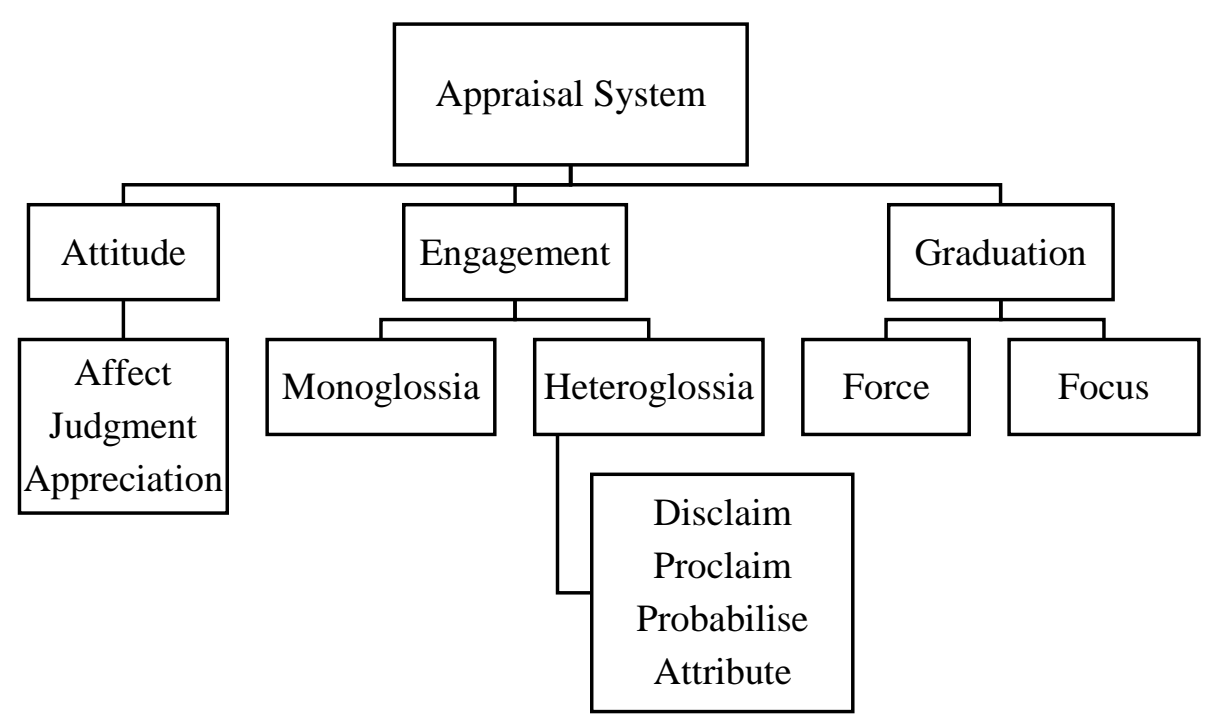

Attitude deals with the feelings or emotional reactions, judgments of behaviors and evaluation of things. Then, the engagement refers to the source of attitudes and the play of voices around opinions in the discourse. Furthermore, graduation attends to the feeling which amplifies and categories blurred in grading phenomena. Attitude refers to the valuation of a person, place, thing, or matter. It contains the interpreting of emotions, ethics, or aesthetic which can be defined to positive or negative attitude (Martin \& White, 2005). In addition, there are three categories of attitude such as affect, judgment and appreciation.

Affect deals with the interpretation of emotional reactions resources, for example the feeling of happiness or sad in a particular event. It also relates to expressing positive or negative feelings of emotional reaction, such as happiness or sadness, confidence or anxiety, interest or boredness. Judgment concerns with the behavior resources according to various normative principles. It relates to the attitude toward the behavior which is admired, criticized, praised, or condemned. Appreciation involves the semiotic and natural phenomena evaluation through the ways they are valued or admitted in a specific area. It is able to be related to affection, perception, and cognition.

\section{RESEARCH METHOD}

This study is a case study on promotional video of Lombok tourism 
destinations. The source of data in this study was a Lombok tourism promotional video in the YouTube account official Indonesia tourism with the duration of 03.43 minutes from https://www.youtube.com/watch?v=BbkFE_K_t0c. The verbal data were the utterances produced during the selected scenes containing the adjective. There were several steps to collect the data. They are: 1)watching the video and selecting the scenes during the utterances produced by taking a screenshot, 2) writing the transcription to identify the text from the video,3) selecting the transcription to find the adjective of the appraisal language, 4) selecting the captured scenes which contains the appraisal language.

The verbal data were all utterances produced during the selected scenes that consist of the adjectives that were described and analyzed based on Martin and White's (2005) appraisal framework especially on attitudinal system. The steps are as follows: 1) presenting the scene, 2) describing the captured scene and the classification of verbal data, 3) analyzing the verbal data using appraisal analysis especially on the attitudinal system into three categories; affect, judgment, and appreciation. The analysis is from the first scene to the last scene. It means that the analysis is sequentially based on the scene in the video.

\section{FINDING AND DISCUSSION}

\section{Finding}

Verbal language used in the video of Lombok tourism promotion accompanies and completes the visual elements of each scene in the video. The visual elements comprise the natural tourisms that consist of beaches, mountains, waterfalls, and other natural views, religious rituals, local culture, and local products. The language used is categorized into an attitudinal system of affect, judgment, and appreciation because they expressed emotional, behavior, and evaluation. There is the evaluation of the attitudinal system of affect and appreciation and the absence of judgment evaluation.

Table 1.Language of Evaluation on Attitudinal System

\begin{tabular}{|l|l|c|c|}
\hline \multicolumn{2}{|c|}{ Evaluation on Attitudinal System } & Appraised & $\begin{array}{c}\text { Language of } \\
\text { appraisal }\end{array}$ \\
\hline Affect & $\begin{array}{l}\text { Refer to the } \\
\text { emotional reaction }\end{array}$ & $\begin{array}{l}\text { Adrenaline rush } \\
\text { local culture }\end{array}$ & $\begin{array}{c}\text { thrilling } \\
\text { enigmatic }\end{array}$ \\
\hline Judgment & $\begin{array}{l}\text { Refer to behavior } \\
\text { resources }\end{array}$ & - \\
\hline
\end{tabular}




\begin{tabular}{|l|l|c|c|}
\hline Appreciation & Refer to the & Beaches, & pristine, \\
evaluation of things & Rituals, & exotic, \\
& Beaches, & tropical, \\
& Island, & beautiful, \\
& Crafts, & colorful, \\
& Resources, & local, \\
& Villages, & authentic, \\
& Villages, & traditional, \\
& Pottery, & distinctive, \\
& Pearls, & exquisite, \\
& voyage & remarkable \\
& Sea-water, & spectacular, \\
& Sea-water, & turquoise, \\
& Volcano, & serene, \\
& Indonesia & wonderful \\
\hline
\end{tabular}

\section{Discussion}

The use of the phrase pristine tropical beaches as the verbal element complemented the image in the video when displaying the image of the beach. The evaluative adjectives pristine and tropical carry an esthetical attitude towards the beach and are categorized as appreciation in the attitudinal system (Martin \& White, 2005) which evaluates the object of nature circumstance rather than the presence of human behavior. Another use of the phrase pristine tropical beaches as the verbal element complemented the view of a beach in a low tide in which it shows some colorful boats in the edge of the beach without the fisherman rather two persons which drive in one of the boats. In addition, the word pristine relates to the original condition, fresh, clean, and flawless beach. It is in line with the stranger hood perspective of tourism advertisement (Dann, 1996). Then, the word tropical is related to the typical hot climate. This verbal element provides information about the nature or environment condition in Lombok. The appreciation classification of the verbal element gives the positive evaluation towards the nature or environment condition in Lombok, in particular, the beaches in Lombok Island.

Another evaluation uses the expression of exotic rituals as the expression for the view of Hinduism rituals in Lombok. The word exotic in the phrase carries an admiral towards the Hindu culture and is categorized as appreciation of reaction in attitudinal system (Martin \& White, 2005).The verbal element fulfils complementary role to show the circumstance of the Hinduism ritual in the temple which cannot be found in common place. In addition, the word exotic is related to attractive or striking things because of extraordinary things. Then, the world ritual is related to the religious action or types of behavior as the characteristic of a particular religion to describe this scene. From this evaluation, it can be summed up that Hinduism rituals in Lombok where Muslim is the majority of Indonesia provides an insight of exoticism of Lombok as one of the diversities in Indonesia.

The use of language of evaluation in the beautiful island of Lombok is to 
display three scenes, one of which takes place in Hindu temple and two of which take place during sunset view in the ocean. The same as the previous evaluative adjective of exotic, the word beautiful carries an esthetical attitude towards the culture in which evaluates the object of culture as the expression of appreciation of reaction. Therefore, the expression of beautiful island represents the beautiful culture in Lombok Island. Moreover, the verbal element used fulfils a balancing role to show the circumstance of the beauty of Hinduism ritual culture in the temple or Hinduism holy building and also the nature. In addition, the word beautiful is related to the high standard of the things. Then, it is pleasing to the senses or mind aesthetically.

Another attitudinal system of appreciation is the use of the word colorful that shows appreciation of composition (Martin \& White, 2005) towards the craft or the weave products. The dominant part of the weaving activity in colorful results is balancing the verbal element to take part in appreciation classification of the attitudinal system because it is evaluating objects of colorful weaving fabric. It is used to show the circumstance of the colorful weaving production which cannot be found in other locations. In addition, the word colorful is related to the fabric which has many or various colors and makes a full interest. Then, the word craft is related to the product of the villagers involving skill in making things by hand such as the weaving production.

Moreover, in displaying the scene of the white petals flower blows in the sky, the phrase created from local resources as the verbal element complement the scene. The word local shows an esthetical attitude towards the blowing petals flower in Lombok so that it is categorized as appreciation which evaluates the object of nature. The blowing petal flowers are considered to be a special moment because it is not commonly found in other parts of Indonesia. Therefore, it is emphasized as the local resources.

The phrase authentic traditional village is used when the video shows the traditional house in Lombok where there are many people gathered under the wood roof in front of the house. Some are sitting on the wooden carpet and some of them are sitting in front of the house facing each other. The capture is completed by food ingredient and cooking utensils with the background of other traditional houses and motorcycles. The words authentic and traditional are appreciation of valuation (Martin \& White, 2005) towards the house building in one of the villages in Lombok Island. The use of those adjectives represents the authenticity perspective of tourism advertisement (Dann, 1996). It is categorized as the appreciation of the attitudinal system which evaluates the object of the village (Martin \& White, 2005). Instead of displaying such scenes, the evaluations words of authentic and traditional are also used when displaying another view of a traditional house in the straw-roof traditional house of Lombok Island. The word authentic is related to the original or the genuine of the traditional house building. In addition, the word traditional is related to the habituality of the building used and long established by the ancestors in this village. This description of the traditional houses in Lombok provides special tourism 
attractions that are distinct from other places. This is one of the strategies in promoting tourism destinations.

Another evaluation is also used when displaying the scene of the variety of potteries shape and size. Then, small potteries are depicted in the sharpness of focus, while the big potteries are depicted in blurry. The use of the expression distinctive potteries refers to the pottery products in Lombok. The big-size of the pottery frame has a significant role in giving information about one of the heritage cultures of Indonesia. It can be interpreted that the scene shows an offer to the viewers for enjoying the local resources product of pottery which is not easily encountered in other places. Therefore, the use of the expression of distinctive pottery village for this scene strengthened the visual element to show the original craft from the local resources in Lombok. The word distinctive is related to the characteristic of pottery products by local people in Lombok which serves to distinguish them from others.

Evaluation of another tourism aspect, pearl as one of the products in Lombok Island, also uses the appreciation resource exquisite pearls. In the video, there are two scenes displaying pearl strands in which some are depicted in blur. One scene displays a necklace or bracelet and the other is a stand of colorful pearl rings. The word exquisite serves an esthetical attitude towards the pearl jewelry in Lombok. It is categorized as appreciation in the attitudinal system which evaluates the object of the pearl in Lombok. In addition, the word exquisite is related to extremely beautiful and typically delicate pearls. Then, the world pearl is related to a round lustrous form within the shell of a pearl oyster which is highly prized. These influence the visitors to consider Lombok as one of the tourism destinations and worth visiting because of the good chance to enjoy the luxury of the available jewelry.

Further evaluation of Lombok tourism destination is the exposure of two scenes in the ocean displaying women. One is a woman who wants to go down from the boat, and at that time the man behind her who is the boat driver holding the boat for the woman. In addition, the background position shows the other boat in the ocean. Then, the woman is depicted in a detailed texture or in sharp focus while in the left and the right side depicted blur. The other is a woman playing in the clean beach. Furthermore, to complete the scenes, the phrase of embark on remarkable voyage is used to express the extraordinary moment. The word remarkable in the phrase holds an admiral towards the voyage from the ocean and is categorized as appreciation in the attitudinal system which is evaluating objects by reference to assess the long journey involving travel by the sea. The language element used fulfils a complementary role to display the circumstance of striking voyage from the ocean using the boat. In addition, the word remarkable is related to striking things or worthy attention. Then, the world voyage is related to the long journey which is typically by the sea to describe these scenes.

Meanwhile, another evaluation concerning Lombok beach is exposed through a woman under the sea who is diving and the display of the corals that indicated the 
condition under the sea. Furthermore, the phrase a thrilling adrenaline rush harmonizes the display of this scene. The word thrilling in the phrase brings an admirer towards the nature under the sea and is categorized as an effect in the attitudinal system that evaluates objects by reference to assess the feeling of diving activity.

The dominant part of the corals under the sea and the diver is balancing the verbal language used to take part in affect classification of the attitudinal system. Moreover, the expression is to show the circumstance of a thrilling feeling when diving under the sea in Lombok. The word thrilling is related to the circumstance of beauty in a dramatic and eye-catching way.

The next scene in the video is where a surfer in the middle of sunny Lombok sea. It highlights the surfing activity in Lombok sea. The phrase spectacular turquois water is used to complete the exposure. The word spectacular is related to the circumstance of beautifulness. Then, the word turquoise is related to a greenish-blue color of the sea. The same as other evaluations words, those words carry appraisal to the objects of the surfing activity. The scene shows an offer to the viewers enjoying the great place for surfing activity in Lombok sea.

Concerning cultural aspects that can be enjoyed by the tourists in the video is the local culture shows. There are five people who are wearing the traditional cloth or costumes for the performance in the night time. Furthermore, while displaying this scene, the phrase celebration of enigmatic local culture as the language of evaluation completed the scene. The word enigmatic is related to difficult to understand or mysterious. Then, the word local is related to the performance belonging to a particular area in Lombok. Enigmatic local culture is the mysterious local culture performance in Lombok which is held outdoors. The word enigmatic in the phrase is an admiral toward the local culture show and to assess the reaction of behavior from the local culture show. Another natural element of a tourism destination in Lombok Island is the presence of waterfalls. Using the expression of the phrase crystal-clear water as the language of appraisal is to realize the view of flowing water. The word crystal-clear is related to being extremely clear and transparent like a glass condition of water. It establishes the esthetical attitude towards the clean and fresh water in Lombok waterfall. The appreciation resource of the attitudinal system assesses the object of the water condition of the waterfall.

The last tourism destination worth visiting in the video of Lombok tourism is mountain and volcano. The mountain scenery is depicted with the greenish plants in sunrise time which makes the atmosphere peaceful. Therefore, it correlated with the complementary of verbal language a serene volcano because of the peaceful nature atmosphere in the mountain. The word serene is related to the calm, peaceful and untroubled condition in the mountain. It relates to the condition of the mountain and appraises nature rather than the presence of human behavior.

The scene in the video is closed by the phrase wonderful Indonesia. It displays 
the view from the top of Lombok Mountain. The word wonderful is related to extremely good, inspiring delight and admiration toward the natural view from the top of the mountain side in Lombok. The scene shows one of the marvelous views from the top of the mountain. Therefore, the scene shows an offer to the viewer's enjoying the wonderful view of the white cloud, the mountain, and the ocean at the same time in Lombok Island as part of Indonesia.

The promotion video about Lombok tourism destination provides particular information that is presented in the form of evaluation. Positive evaluations are used in all scenes while displaying each destination worth visiting. The promotional video of Lombok tourism always portrayed all destinations in positive ways with the aim of promoting tourism aspects and ignored other attitudes. However, the use of positive appreciation is important as a resource of the social significance of the video. This strategy is needed to provide the viewers the first impression of Lombok destination (Wu, 2018). Instead of the use of appreciation, evaluation in terms of affect is also used to describe the destination, namely the surfing activity in Lombok and its local culture. This evaluation of affect expresses the video makers as if they experienced visiting the destination and found their good feelings.

In the video, there is an absence of appreciation of judgment. The absence of judgment should be considered by the government officer or video maker of tourism promotion because it could be a good chance to teach people or tourists how to respect and take care of nature despite their excitement when visiting the tourism destinations (Isti' anah, 2020).

The video displays beaches, mountain and volcano, people, traditional lifestyles, pottery as local products, temple, pearl, traditional performance, highlighting all good tourism destinations in Lombok Island. The video could also adopt the concept of authentic tourism as tourists seek them out (Salim et al, 2012). Then the way of using language of evaluation strategies on the video became the important factor to persuade tourists.

Thus, from the overall point of the advertisement, in this matter in the form of video completed by the verbal language, is one of the instruments of communication that has the intended effect to persuade and convince the audience and call them to action (Jafari \& Mahadi, 2014). From this purpose, an advertisement, whatever its form, must be fashioned or generated in a way which influences the potential tourists' attitude, stimulates their behavior, and accordingly, results in increased visit to the destinations.

\section{CONCLUSION}

The tourism destination on Lombok Island promoted in the Youtube video covers the presences of beaches with their surrounding views, Hinduism ritual, temple, sunset view, white petal flower, weaving activity, fabric drying, traditional 
village and house, pottery products, pearl jewelry, diving and surfing activities, local culture show, waterfall, volcano, and mountain scenery. They are portrayed as their physical existence. All the tourist attractions are evaluated in positive ways, both appreciation and affect, and absence of judgment evaluation that deals with attitudes to people and the way they behave their characters. Positive evaluation on appreciation on the attractions expressed the worthiness of the resource to be visited and enjoyed with. Meanwhile, evaluation on affect that deals with emotional feelings also suggests to the viewers that the attractions provide positive tourism experiences. All of the positive evaluation resources merge to be one of the representations of Lombok Island as one of tourism destinations in Indonesia worth visiting.

One of the pedagogical implications from the study is that it is useful for the purpose of teaching adjectives using authentic materials, in this matter the use of advertisements. It can be used to teach the way to describe the physical attributes of things the students see, hold, or feel. Moreover, in a broader view, it is also beneficial for exploring language, paralanguage, and culture from the scene in the video advertisement.

\section{BIBLIOGRAPHY}

Dann, G. (1996). The language of Tourism. A sociolinguistic perspective. Oxford: CABInternational. Google Scholar

Eggins, S. (1994). An Introduction to Systemic Functional Linguistics. London: Pinter Publisher. Google Scholar

Hassan, H. (2014). The Representation of Malaysian Cultures in Tourism Brochures. Procedia Social and Behavioral Sciences. 118. $140 \quad-151$. doi:10.1016/j.sbspro.2014.02.019

Isti'anah, A. (2020). (Re)evaluating language attitudes on Indonesian tourism website: A study on ecolinguistics. Studies in English Language and Education, 7(2), 622-641. Google Scholar

Jafari, S.M and Mahadi, T.S.T. (2014). The Language of Advertisementand Its features and Characteristics: Investigating the Issue from a Deeper View. International Journal of English and Literature (IJEL), 4 (6): 9-14. Google Scholar

Kim, D. Y., Hwang, Y. H. \& Fesenmaier, D. R. (2005). Modelling Tourism Advertising Effectiveness. Journal of Travel Research. 44 (1), 42-49. doi.org/10.1177/0047287505276590

Liu, X. (2010). An application of Appraisal theory to teaching college English reading in China. Journal of Language Teaching and Research.1(2), 133135. Google Scholar 
Locksley G. (2009). The Media and Development: What's the story? Washington, D.C: The World Bank. Google Scholar

Martin, J. R. \& Rose, D. (2003). Working with Discourse: meaning beyond the clause. London: Continuum. Google Scholar

Martin, J. R. \& White, P. R. R. (2005). The language of evaluation. Appraisal in English. New York: Palgrave. Google Scholar

Molina, A. \& Esteban, A. (2006). Tourism Brochures: Image and Usefulness. Annals Tourism Research.33(4): 1036-1056. doi.org/10.1016/j.annals.2006.05.003.

Salim, M. A., Ibrahim, B. N., \& Hassan, H. (2012). Language for tourism: A review of literature. Procedia-Social and Behavioral Science, 66, 136-143. https://doi.org/10.1016/j.sbspro.2012.11.255

Salim, M.A. M., Ibrahim, N. A., \& Hassan, H. (2014). Promoting Diversity Via Linguistic and Visual Resources: An Analysis of the Malaysian Tourism Website. LSP International. 1, 1-14. https://DOI: 10.11113/1spi.v1n1.6

Wu, G. (2018). Official website as a tourism marketing medium: A Contrastive analysis from the perspective of appraisal theory. Journal of Destination Marketing \& Management, $10, \quad 164-171$. https://doi.org/10.1016/j.jdmm.2018.09.004

Zhang, Y. (2011). Book review: Richard W. Hallett and Judith Kaplan-Weinger, Websites: A Discourse Analysis Perspective. Discourse \& Communication. https://doi.org/10.1177/1750481311414402b 